\title{
Paternalistic internationalism and (de)colonial practices of Cold War higher education exchange: Bulgaria's connections with Cuba and Angola
}

\begin{abstract}
This paper presents the findings of an archival study on the Cold War higher education exchange between Bulgaria, Cuba and Angola carried out at the Open Society Archive. While research on the internationalisation of higher education mostly focuses on the introduction of new managerial governance and global rankings, scholars studying socialist countries mostly address the intricacies of student exchange. By contrast, I focus on policy transfer and expert exchange, and discuss both the limitations of the framing of the subject in both Western liberal and socialist official sources, and the asymmetries of the exchanges between socialist countries. Exploring the exchanges between Bulgaria on one side, and Cuba and Angola on the other, my study shows that East European socialist countries based their cooperation with developing countries in the Global South on the premise of the dominance of Eurocentric knowledge and extractivist practices in return for knowledge and technology.
\end{abstract}

\section{Introduction}

During recent decades, growing research on the internationalisation of higher education (HE) has been based on the premise that intensive internationalisation and competition only really started with the introduction of new managerial governance (Frank and Meyer 2007; Marginson 2008). Its subsequent discourses of 'knowledge-based economies' and global rankings, the dominance of research-intensive higher education institutions in the Global North and of English language as means of scientific production, these authors convincingly argue, have accelerated the international competition over the ability of individual institutions 
and national systems to attract talent, funds, research awards and to achieve 'academic excellence'. However, this approach, focused on developments in the Global North, omits the historical reality that during the Cold War a significant effort was made on both sides of the Iron Curtain and by non-aligned countries to enhance scientific cooperation within blocs and competition across dividing lines (Romano and Romero 2014).

In parallel to the above-mentioned research literature, over the last two decades a growing scholarship has emerged addressing global connections and expert exchange in HE during the Cold War. Focusing on African-American and African students coming to the Soviet Union, the majority of books and articles in this research field have discussed a number of topics in depth. For example, scholars have studied the institutionalisation of a socialist internationalism; the opening/closure of exchange opportunities and institutions; the symbolic and material benefits for students; the ideological training they were exposed to; the racism they faced and their anti-racist mobilisations (see, for example, Filatova 1999; Hessler 2006; Matusevich 2008; Djagalov and Evans, 2009; Nash 2016; David-Fox 2016; Katsakioris 2017 inter alia). Written mostly by historians of the Soviet era, this research literature does not focus on policy travel or alternative HE models. Recent scholarship concerning exchange students in East Germany (Pugach 2018; Burton 2019) or Czechoslovakia (Holeckova 2018) has been similar in focus. An emphasis on policy travel has been present in the work on Cuban exchange with other socialist countries, yet with a strong focus on South-South development, aid, and exchange (see Hatzky 2012; Hickling-Hudson et al 2012). The role of the East European socialist countries in relation to Latin American or African regimes has so far remained mostly outside this latter discussion.

Against this background, this paper presents the findings of an exploratory study which is part of a broader research on alternative models of higher education (HE) policy travel during the Cold War in historical perspective. It reflects the results of two-month research visit at the 
Open Society Archives (hereafter OSA) in Budapest in early 2019. My research aimed to explore if and how the competition between Cold War blocs was framed in journalistic representations and official reports when it came to HE: was this domain only seen through the competition for technological domination, or was it also a question of demonstrating a more equitable (HE) system and better model of social organisation? My working hypothesis was that during the Cold War era, competition was framed in different terms from current scholarship and policy in the HE field: namely, the competition was to prove which bloc produced a more equitable and just model of redistributive and socially just education. To explore this hypothesis, I carried out an exploratory study of archival materials on HE policy and exchange during the Cold War. I paid special attention to how socialist bloc-led cooperation efforts were portrayed by Radio Free Europe, Western and Socialist bloc outlets and reports present in OSA's rich collection from this period. In what follows, I first report on the research carried out in the OSA and the limitations encountered at the intersection of my own research design and the materials available at the archive. These concerned the absence of or rather formalistic reporting on the subject on both sides, which challenged my anticipation of discovering an alternative and nuanced framing of competition or focus of reports differing from what was present in the current scholarship. I then go on to discuss some interesting findings from the research and insights into the field of knowledge exchange during the Cold War that I was able to access at the OSA.

To discuss my findings, in the paper I engage concepts such as decoloniality (Santos 2013), cognitive justice (Vivanathan 2006), extractivist capitalism (Gómez-Barris 2017), paternalistic versus mutually beneficial internationalism (Alamgir 2013; Apostolova 2017) and post-colonial semi-peripherality (Ginelli 2018). I claim that while Eastern European state socialist regimes did not engage in extractivist capitalism, unlike their Western liberal counterparts, they still engaged in asymmetric practices of knowledge exchange during the 
Cold War. I discuss some mechanisms through which these practices of paternalistic internationalism reproduced East Europe's semi-peripheral position and relation with the developing world as a periphery. I show how, despite decolonial rhetoric, they came from an Eurocentric understanding of knowledge in which peripheral countries had little to contribute apart from having students trained - often through 'civilising' and racializing practices - in a master-disciple relation, while remaining the suppliers of labour force and primary materials in return for knowledge and technology.

On this basis, I propose some theoretical reflections on new ways to frame scholarship on the Cold War knowledge exchange through the lens of (de)coloniality and cognitive (in)justice. I claim that the global history of Cold War aid and development between socialist countries should be studied in further depth to inform both contemporary studies of the internationalisation of higher education and contemporary programs of internationalist solidarity more widely. I suggest future studies engage more seriously with the question of whether knowledge exchange between socialist and non-aligned countries during the Cold War aimed to transgress the hierarchies of knowledge production posed by the dominance of Euro-centric knowledge or whether it reinforced them. These studies should examine to what extent the geopolitical positions of different socialist countries - more or less proximate to Eurocentric science and knowledge production - relied on their ability to frame the terms of and benefit from international HE cooperation. Only by learning from the achievements and mistakes of the past can new experiments of international exchange and solidarity build horizontal relationships based on mutual learning.

\section{Methodology and case study choice}

The Open Society Archive (OSA) is one of the biggest archives on the Cold War, containing information about the socialist bloc both as seen from individual socialist country files and as seen through Western media and the Radio Free Europe collection. The latter was the media 
most engaged to cover the socialist bloc, if through a specific ideological lens. Thus, this archive was uniquely placed to allow me to explore more than one country and to cross-sect narratives from both sides of the Iron Curtain. Given the large number of countries and variation in languages that a study of Cold War socialist exchange could entail, for my OSA exploratory research I focused on a small number of countries and their exchange. I was particularly interested in how HE reforms have been portrayed when it comes to countries in the socialist bloc, and their links with Latin American and African socialist countries in specific. For the purpose of this article, I focus my attention on the exchange between Bulgaria, Cuba, and Angola. Even though I did explore other countries, topics, and international links, I made this choice for two reasons. First, I was particularly interested to see how a country like Bulgaria - given its peripherality within the socialist system, while being very subservient to Soviet foreign policy throughout the Cold War - intervened in the higher education and expert exchange. Secondly, it was also in the Bulgarian subject file that I observed a surprisingly higher number of references and documents related to African socialist countries, in comparison with other socialist bloc countries, which was an interesting discovery, attesting to that country's active role in the East-South exchange.

Having identified Bulgaria as a starting point of my inquiry, I looked at the ways that its HE reforms were reported and at its relationships when it came to higher education exchange in two directions: on the one hand with Cuba, and on the other with African socialist countries. Cuba was interesting to me as it has been the longest-lasting socialist regime in Latin America. It also had unparalleled intensive connections with both Eastern European and African socialist countries. I also looked into the connection between Bulgaria and Cuba and African socialist countries, exploring what the archive held on their links to different regimes. While I explored links with all African socialist countries, for this article and in the last, most intensive part of my study, I focused especially on Bulgaria's links with Angola. The reason 
for the focus on this country was two-fold. To begin with, Angola was one of the two African socialist countries (together with Mozambique) best represented in the archive in relation to its Bulgarian connection, and in general. Furthermore, in a document from November 1977, of all sub-Saharan African countries Bulgaria was reported to have developed the most intensive cooperation with Angola (HU OSA 300-20-1:191/7, 11/11/77). Interestingly, the Angolan knowledge exchange with Cuba has also been the subject of recent scholarly work (see, for example, Hickling-Hudson et al. 2012). Cuba's educational mission in Angola has been called "the largest, longest, and most varied civil cooperation in Cuban history and ... a unique example of South-South cooperation" (Hatzky 2012: 141). Thus, by focusing on Angola I could explore if there was any bilateral or even trilateral development in HE exchange between these three countries. I did, however, also cross-check files of other African socialist countries such as Ghana, Tanzania, Ethiopia, Burkina Faso, the Democratic Republic of Congo and others to identify divergent trends in their relation to Bulgaria, but no significant information on this topic was to be found.

To explore these links at the OSA I consulted a number of collections that appeared relevant. Beyond the secondary literature consulted, summarily my study accounts over seven hundred pages of twenty-eight archival boxes, further two hundred documents online. I first explored the RFE Subject Files with focus on the Bulgarian Unit Subject Files (HU-OSA-300-20-1; for details of archival boxes used, see the reference list below). There I examined the files concerning Party Education; Culture and People's Education; University Education; Foreign Relations; Relations with other countries; Labour Bulgarian workers and Specialists in Foreign Countries; Foreign Trade, and Youth Student Organisation. I also consulted the RFE Bulgarian Unit Subject Card Files (HU OSA-300-20-2). I studied files related to HE policy (General, public and foreign universities; Foreign students). There I also explored the materials on foreign policy when it came to Cuba and African socialist countries. I also 
examined RFE Records of Index on Censorship: (HU OSA 301-0-3) Country Files with a focus on Cuba, and Angola and related specifically to the General, Background, and Education information files. ${ }^{\mathrm{i}}$

Additionally, I examined the files from two different collections. I went through the files on the international communist youth movement (HU OSA 300-7-9 Subject Files Relating to the World Communist Movement, archival box 55), in case discussions of higher education policy or reform were accounted for there. This was not the case. It was interesting and instructive, however, to understand from the documents collected around the international Youth Meeting in Sofia in late July- early August 1968 (i.e. in the direct aftermath of the Prague Spring) how brutally repressive the Bulgarian police were to foreign students. Members of student groups from abroad, including those from African socialist countries and Cuba, present and openly expressing discontent with the Soviet invasion of Czechoslovakia at the meeting were severely harassed and beaten up, which confirms findings from literature on how socialist regimes treated dissenting foreign students (see, for example, Hessler 2006). On the other hand I consulted the documents under the heading 'Academic' (HU OSA 300-79 Subject Files Relating to the World Communist Movement, 'East-West' and 'international', archival boxes 41-43). Where focusing on academic, rather than political exchange, these materials had a specific subheading 'East-West' and focused particularly on scholars from Eastern Europe going to conferences or undertaking longer exchange stays in the West, and more rarely - of Western scholars contributing to conferences and knowledge exchange in the East. Yet exchanges with scholars from the developing world were not mentioned in this collection. This absence is telling of how the 'academic exchange' was framed in documents collected in both state socialist and liberal democratic media and official documents - with reference mostly to Eurocentric science and knowledge production. I develop further thoughts on this subject in the discussion section of this paper. 
I sorted the documents by different initial and emergent topics, performing thematic analysis and coding. Initial topics of interest included 'student exchange', 'policy exchange', 'academic exchange', 'East/West framing a/symmetries'. These were quickly supplemented with emergent topics like 'foreign trade', 'international development and aid', 'a/symmetry of relations', 'extractivism', 'de/coloniality'. Rather than looking for ways to prove or disprove my initial hypothesis, I engaged in exploratory study that would allow me to relate to my initial intuition without closing avenues for new discovery. The findings presented below respect this logic of discovery and allow me to outline new ways to extend the framing of HE exchange around topics of internationalism, development, and decoloniality: themes that I will develop below but also in future research on Cold War higher education.

\section{Findings: (asymmetric) practices and (mis)representations}

The documents I explored at the OSA collections contained very little information about the higher education exchange between the countries in the narrow sense of policy, academic and student travel. Detailed analysis of the achievements and limitations of the socialist regimes' higher education policies was mostly not present in the RFE and Western journalist reports. These reports did not juxtapose the HE reforms in the socialist bloc with achievements in Western liberal democracies in order to claim dominance over the latter. Neither did the materials from the socialist press detail policy moves or frame them in competition to Western successes or failures in HE massification. Instead, most articles and documents coming from both sides of the Iron Curtain, engaged in rather dry reporting about the developments in the socialist bloc and never in comparison with developments on or policy competition with countries in the enemy bloc. Beyond usually brief reporting in passing, concrete policies were not discussed in detail, not even for the purpose of critique or praise. In the rather rare occasions in which any mention of such reforms happened, the analysis confirmed already-established ideological frameworks on both sides. 
This was the case with a report on Cuba prepared by RFE. Scholars have discussed both the internal HE policies and the alternative practices of HE exchange as rather based on solidarity and thus breaking up with an over-ideologised developmentalist approach (Hatsky 2012; Gonzalez et al. 2012). Yet the discussion on Cuba's education policy as seen by RFE did not acknowledge such achievements (Figure 1). Whilst the policy was reported at times verbatim, with its "focus on individual existence, a permanent process of study and work, personality development and integration and communication with society", the judgment of what this meant was read as unequivocally "authoritarian". This interpretation was set against the liberal human development philosophy that such statements evoked, and which was not in contradiction to the trends in Western pedagogy:

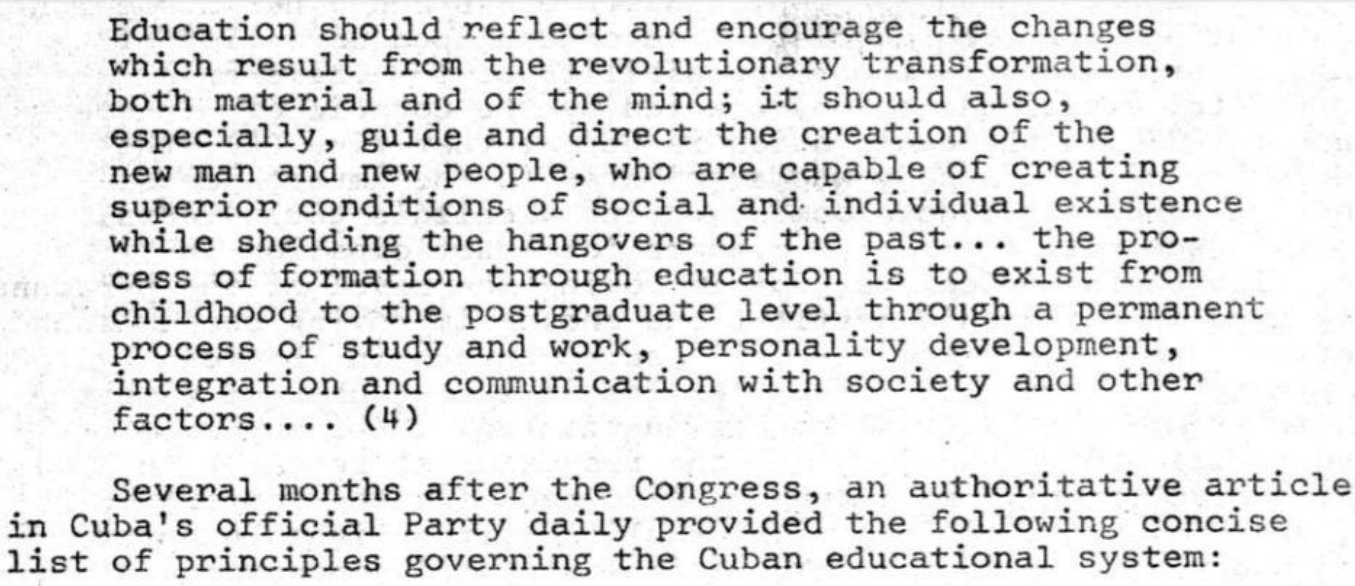

1) Channeling education toward concrete objectives.

2) Establishing close links between the school and Iife.

3) Training the new generations for work and in work.

4) Educating for the collectivity.

5) Combining conscious but firm discipline with the most strict respect for the personality of the student. (5)

On the basis of these brief representative statements of Cuban educational philosophy, there is little doubt that the country's educational system is predicated on authoritarian principles and organized along totalitarian lines.

Figure 1: "Educating the "New Man" in Cuba", 9 February 1973. HU OSA 300-8-3-1460,

p.3 [Electronic Record]: http://hdl.handle.net/10891/osa:cb605364-afbe-468f-b6a1- 
At the same time, the documents which I explored, especially in the Bulgarian Subject file, were particularly intriguing and revealing, and allowed me to look into internationalisation via further lenses: internationalism, development an expert exchange. This was especially when it came to foreign trade (300-20-1, archival boxes \#191-192). In a way, the reporting on the relations between Bulgaria and Cuba and Angola were very similar, revealing asymmetric and arguably exploitative relations between the former 'second' and 'third' world. Such an asymmetric view of the relations and the lack of mutual knowledge interchange could of course partly be explained by the fact that Cuba and Angola were only recently decolonised countries, with little accumulated expertise. Yet, a larger and more problematic asymmetry has recently been explored in areas other than higher education, for example, workers' exchange (Apostolova 2017) and expert exchange in the field of urban planning and technology (Ginelli 2018). To illustrate and discuss the findings that I consider most intriguing while looking for HE exchange, I now explore a few revealing excerpts which manifest patterns representative of the Bulgarian exchange with other countries as well. They concentrate around the rather asymmetric form of bilateral exchange that, unless indicated below, did not change over time. In the case of Angola, I found similar patterns in the communication, trade and knowledge exchange with other African socialist countries with which Bulgaria was involved in technology and expert exchange, most notably Mozambique and Ethiopia. These findings made me see in new light and reflect on the power dynamic underpinning Cold War internationalism and solidarity: an insight that will most definitely illuminate my subsequent studies on the subject of Cold War HE policies, and which I would indeed like to explore in further depth. 
Bulgaria-Cuba: experts, technology versus sugar, and debt

In the case of Bulgarian-Cuban relations, a report from the Bulgarian Telegraph Agency

(BTA) from 1975 speaks of the economic cooperation between the two countries in terms of "mutual advantage". This advantage, however, is expressed in rather asymmetric ways. On the Bulgarian side, the Eastern European socialist country supplied its Caribbean partner with technologies ("basic machines for the needs of agriculture"), as well as goods ("foodstuffs, chemicals and medicaments"). Bulgaria also supplied Cuba with high-skilled labour in the form of over 500 experts, mostly engineers and doctors. HE cadre exchange did not seem to be an explicit priority zone of exchange between the two countries, unless it went under the rubric "science and technology" (which, as signalled above, was most probably the continuation of technology and expert exchange for industrial production). Other areas of exchange were tourism, veterinary medicine, and communications (Figure 2).

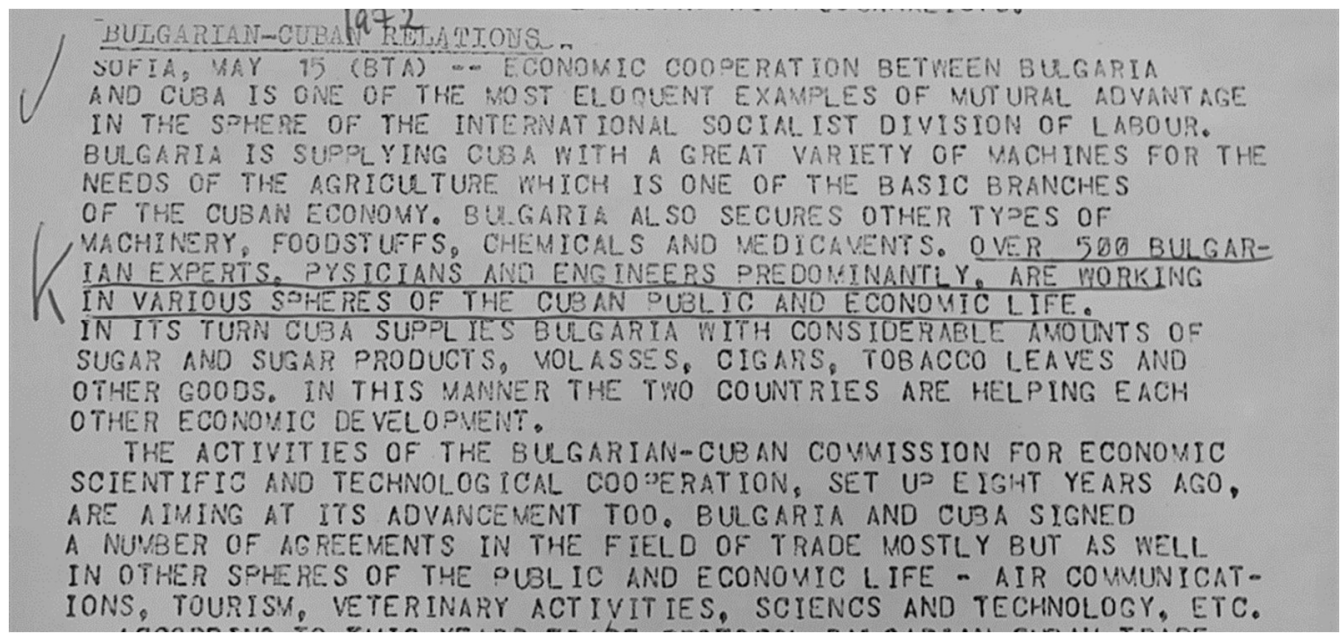

Figure 2 300-20-1:192/10 RFE Subject File Bulgarian Unit Subject Files, Foreign Trade:

Cuba 1967-1992, 15/05/72

Another report from BTA from May 1982 speaks of the interview in Agricultural Banner (Zemedelsko Zname) with José Ramírez Cruz - a leading figure in the Cuban Politburo and of the National Association of Small-Scale Agriculture (ANAP). The Cuban official and 
militant discusses how agricultural workers were invited to and taken around Bulgaria to be exposed to the latest technology and organisational development, which then allowed them to set up cooperatives back in Cuba. Such exchange, happening in the 1980s, twenty years after the Cuban Revolution and its experimentation with agriculture, speaks of continuous understanding of Cuba's need to 'catch up with' and learn from a more 'advanced' country as Bulgaria. The question of exchange of knowledge, in this case vocational and organisational rather than educational and scientific, remains one-sided, with the assumption that one country (Cuba) can learn from the other (Bulgaria), but not vice-versa.

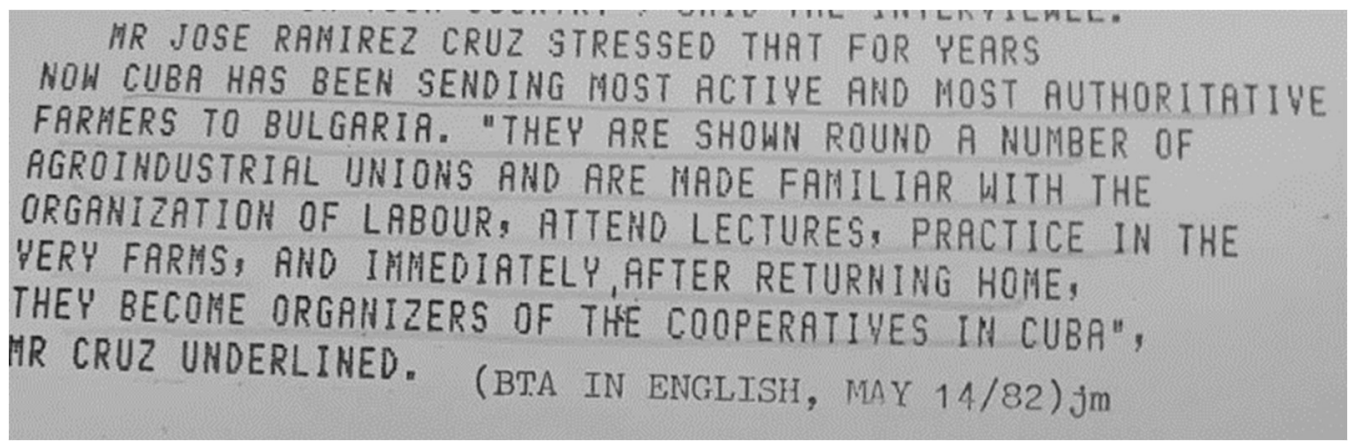

Figure 3 300-20-1:192/10 RFE Subject File Bulgarian Unit Subject Files, Foreign Trade:

Cuba 1967-1992, 14/05/82

This is also shown in a report from the following year, 1983, again in BTA (Figure 4). There it becomes clear that Bulgaria was heavily involved in trade with Cuba: an intensity of trade second only to Cuba's relations with the Soviet Union. Yet whilst it exported machinery and developed infrastructure, there was no similar activity by Cuba in the exchange. Cuba, instead, exported mostly sugar, molasses, citrus fruit, cigars and alcoholic drinks. While the exchange was commended as very beneficial for both parties, it is clear that by the 1980 s it remained quite unequal and hierarchical. Despite the ongoing cooperation and technical exchange, Cuba had not broken up with the single-crop economy developed during the Spanish colonial era (Galeano 2009) or with its role of export of trademark entertainment 
consumption goods for which the island had become world (in)famous during its pro-US rule before the coming to power of the revolutionary government (Perez 2018).

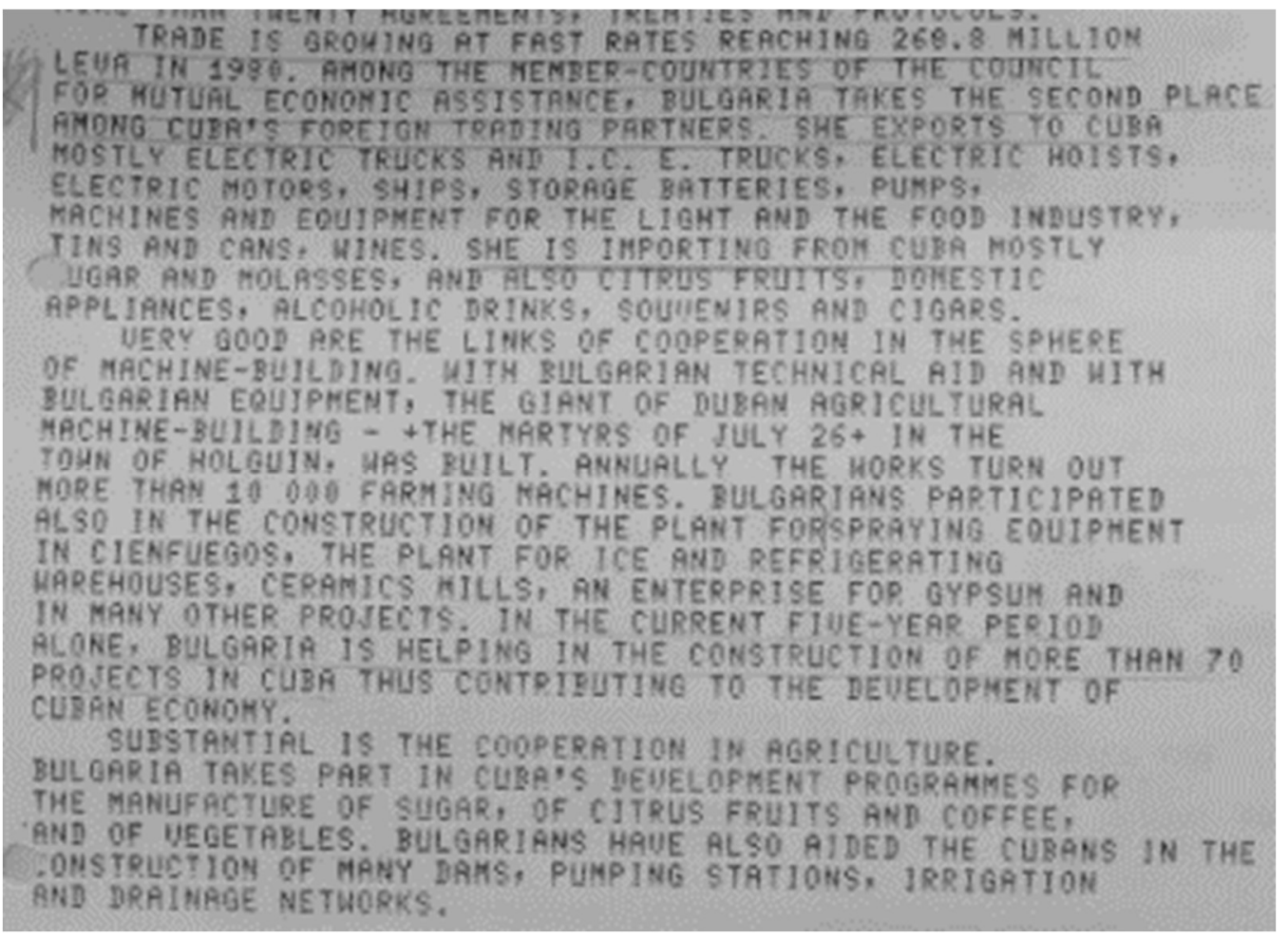

Figure 4 300-20-1:192/10 RFE Subject File Bulgarian Unit Subject Files, Foreign Trade:

Cuba 1967-1992, 18/05/72

At the same time, beyond the extraction of primary sources in terms of both natural goods and food harvest, Bulgaria was also involved in specific financial relations with Cuba. A significant, if low-interest, debt had already been accumulated by this Caribbean islandcountry by 1961, when it was granted US $\$ 5 \mathrm{~m}$ mostly in the form of the purchase of industrial installations from Bulgaria (Figure 5). In this situation Cuba can be seen as positioned at a relative disadvantage - while it imported machinery to develop its agriculture, its produce was dedicated to debt repayment to its creditor (Bulgaria) from which it both bought the machinery and sold the agricultural produce, with little endogenous production of new technology or possible revenue for reinvestment. 
Bulgaria is known to have granted at least two long-term credits co cuba. The first, anounting to 5,000,000 dollars, was agreed in January 2961, the second, whose valuo and conditions of repayment are unknown, in May 1968. It is bolieved that both of repaywe at the usual 2 per cont interest rate and, as Radio Havana loans are at the usua 19 May 1968, are intended for the purchase of Bulgarian industrial installations, such as ice factories, and the construction of cold storago warehouses.

\section{Figure 5 300-20-1:192/10 RFE Subject File Bulgarian Unit Subject Files, Foreign Trade:}

\section{Cuba 1967-1992 18/05/72}

It is only in the late 1980s, when upon a meeting in Moscow in early March 1986 between the heads of communist parties of both countries, Fidel Castro and Todor Zhivkov (and in a programme document optimistically dated 2000), that the two countries started speaking of qualitatively new more equal and symmetric forms of scientific cooperation. This document states as central "the holding of joint research and development, exchange of technical documentation and information, the establishment of joint institutes, scientific research centres and laboratories ... [and] training of their personnel and exchange [of] specialists (Figure 6). It is interesting to trace what follow-up policies and institutionalised practices were put into action in both countries after the signing of this agreement. The critical state of their economic and political development and skyrocketing international debt of both countries at that stage makes the prediction of effervescent exchange activity seem unlikely.

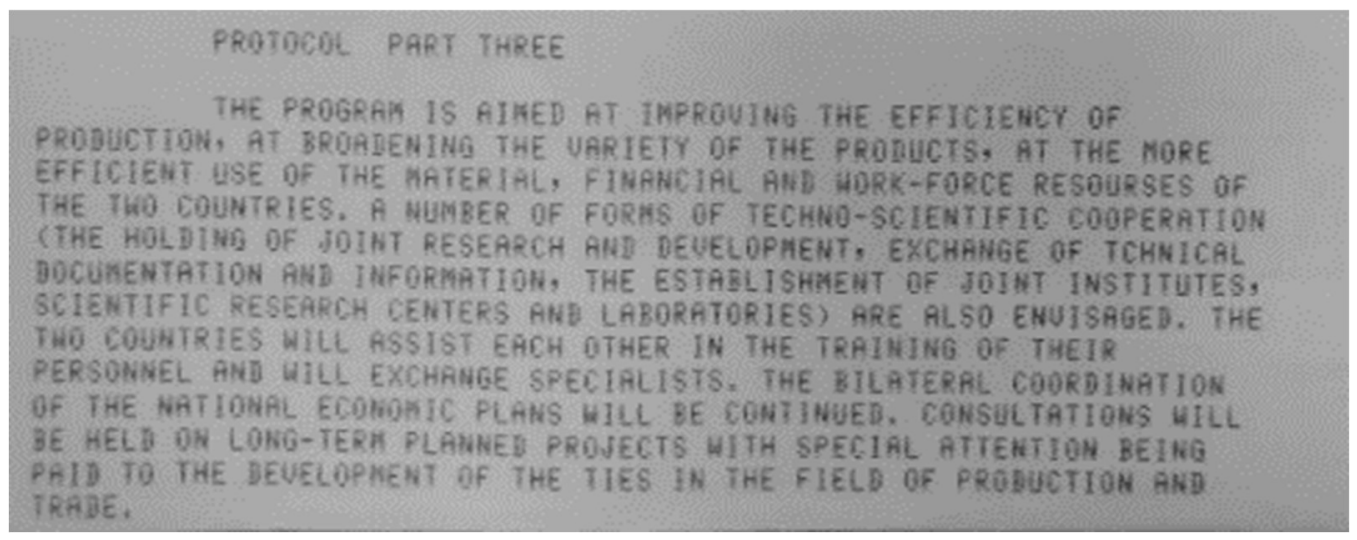

Figure 6 300-20-1:192/10 RFE Subject File Bulgarian Unit Subject Files, Foreign Trade:

Cuba 1967-1992 05/03/86 
Bulgaria-Angola: academics and students vs. phosphates

For the most part, a similar tendency as in terms of cooperation with Cuba is visible when speaking of Bulgarian-Angolan relations. Their exchange, which started in the 1970s after Angola's liberation from Portuguese colonial rule, was more clearly related to the exchange of academic cadres, detailed in the OSA documents. This meant that Bulgarian lecturers were sent to teach academic subjects at some Angolan colleges, while Angolan students could enter Bulgarian academic establishments. In terms of expertise, Bulgaria extended its aid particularly in the field of construction and town planning, mechanical engineering, water, and forestry (Figure 7).

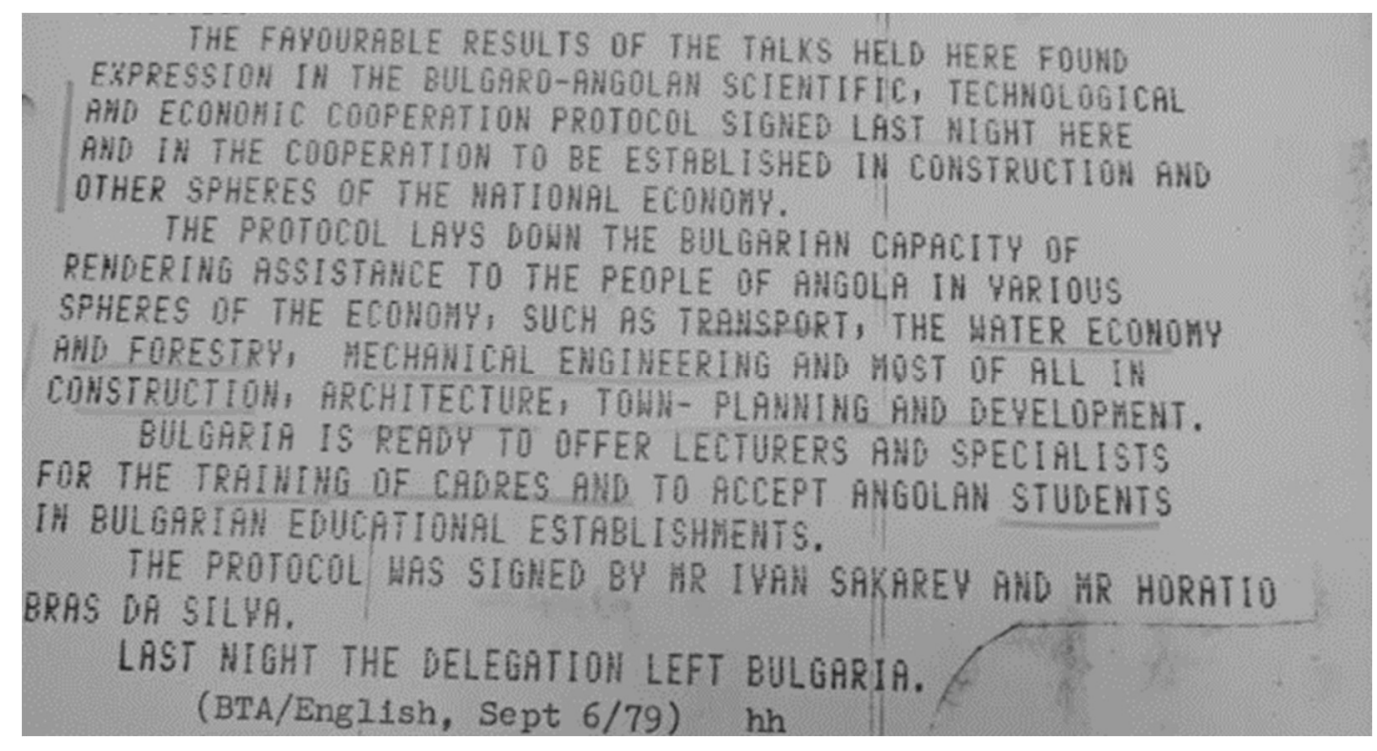

Figure 7 300-20-1:191/7 RFE Subject File Bulgarian Unit Subject Files Foreign Trade:

Africa; Angola 06/09/79

At the same time, what was clear in this exchange throughout the period was that the main Bulgarian interest behind this effort in terms of trade and knowledge exchange relations was framed around Bulgaria's ambition to extract natural resources, especially phosphates, from Angola's rich natural reserves. This exchange meant an overt presence of Bulgarian companies and experts in Angola, exploiting deposits in different parts of the country (Figure 
8). In this, a one-sided extractivism was taking place: an Eastern European socialist country was exploiting the reserves of a post-colonial country in the Global South. Framed as solidarity and aid, this exchange also showed that the Bulgarian government considered the comradely African country as a source of primary resources, but not as an equal partner in a trade and knowledge exchange.

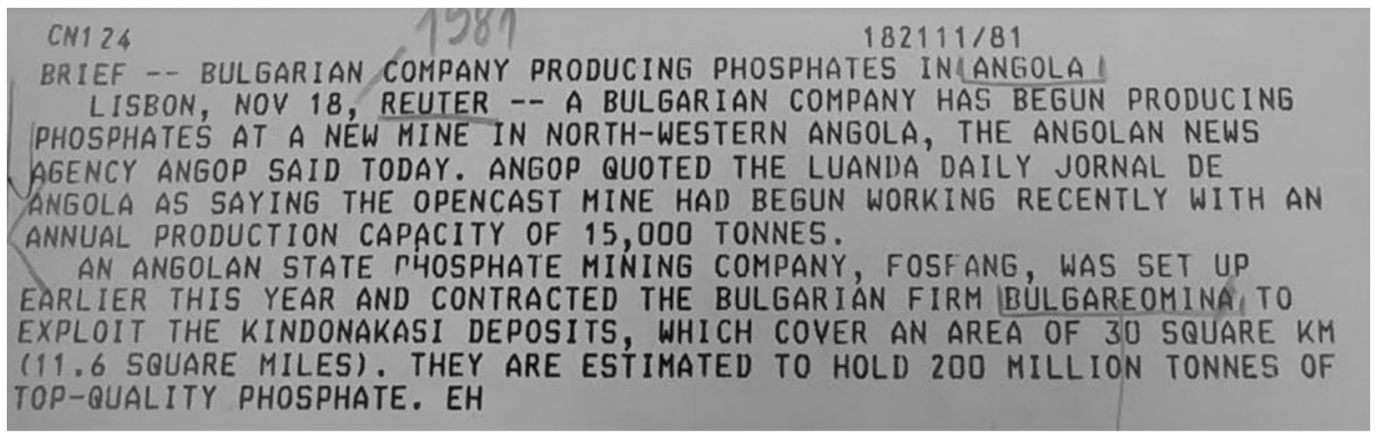

Figure 8 300-20-1:191/7 RFE Subject File Bulgarian Unit Subject Files Foreign Trade:

Africa; Angola: 18-21/11/81

Yet, oddly enough, unlike the dryer and more factual reporting of the meetings between the Bulgarian and Cuban Party heads, upon initiating this asymmetric relationship, the Bulgarian government went out of its way to perform ardent anti-imperialist solidarity. In an agreement from October 1978 (Figure 9) signed between the heads of the two countries, Todor Zhivkov (Bulgaria) and Agostino Neto (Angola), and cited by Bulgarian daily newspaper People's Deed (Rabotnichesko Delo), the First Secretary of the Bulgarian Communist Party stated the country's similarity with Angola. He emphasised Bulgaria's commitment to stand against imperialist forces until "the final liquidation of colonialism, imperialism, racism and apartheid”. Yet, while the Bulgarian authorities performed equality in the exchange, one cannot help but ask: what were the exact theoretical and historical definitions of neocolonialism that the Bulgarian leader was using? To what extent did his and his Party's analysis include self-reflection of the hierarchies of knowledge production and the extraction 
of primary resources in the post-colonial world as performed by Bulgaria and other state socialist regimes during the Cold War?

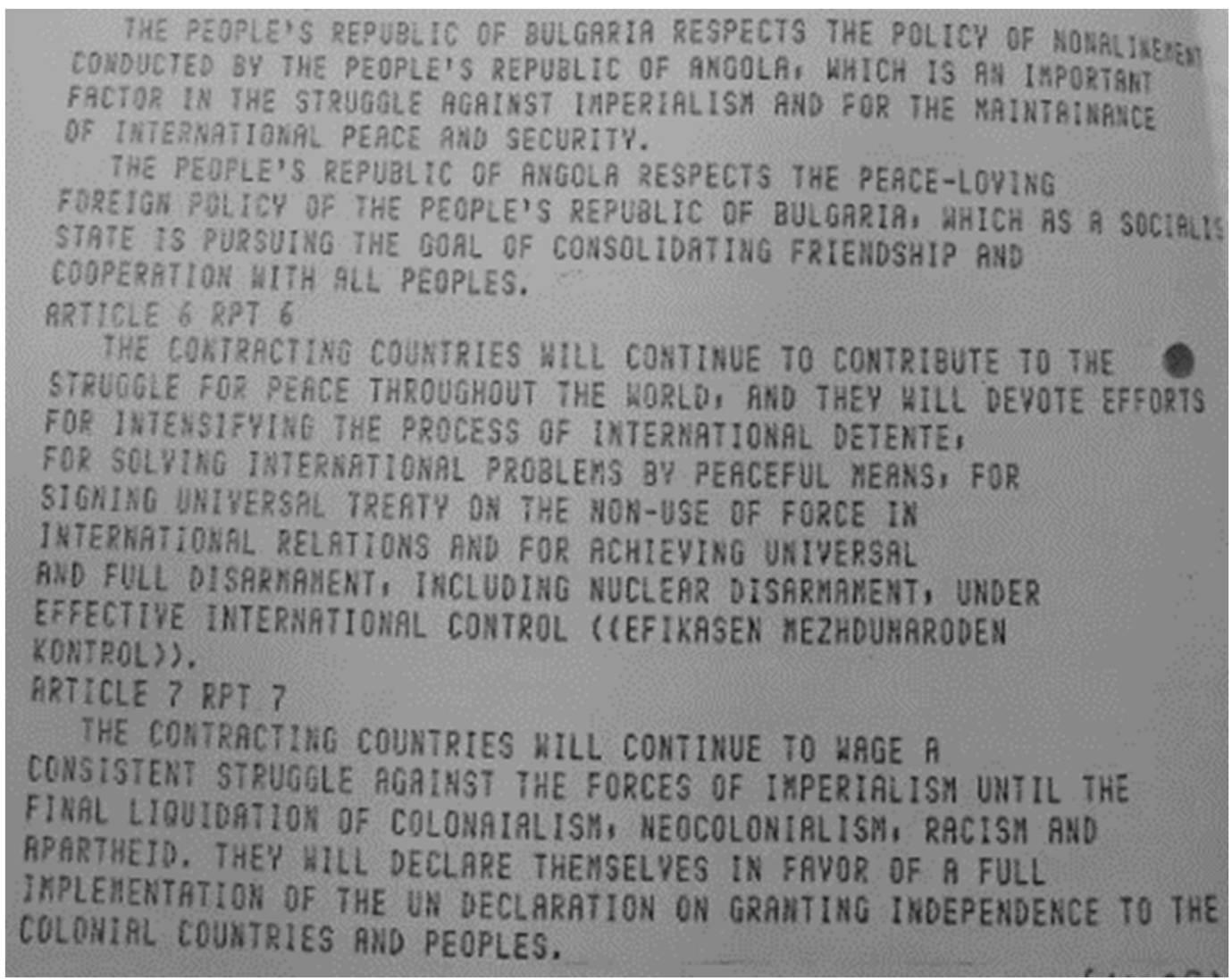

Figure 9 300-20-1:191/7 RFE Subject File Bulgarian Unit Subject Files Foreign Trade:

Africa; Angola: 22/10/78

\section{Discussion: (de)colonial socialist extractivism?}

In his important contribution to the theorisation of post-colonial states, late anthropologist Fernando Coronil explained a mechanism that perpetuates the neo-colonial dependence of post-colonial countries:

Even when these nations try to break free from their colonial heritage, that is, their dependence on the export of primary products, through the implementation of development plans directed at diversifying their economies, they generally need foreign currency to achieve this. But they can only access foreign currency by exporting primary products, which again increases their dependence on exports. Paradoxically, by 
trying to exploit their comparative advantages, these countries that are exporters of natural assets, are frequently reassuming their colonial role as exporters of primary products - a role now redefined in terms of the neoliberal rationality of globalising capitalism. For them, neocolonialism is the next step on from post-colonialism (Coronil 1997: 7).

This model elaborated by Coronil kept coming to my mind while reading the OSA materials when it came to foreign trade between Bulgaria on the one side, and Cuba and Angola on the other. Socialist solidarity and internationalism translated into low interest rates on loans and prices on machinery and labour (Apostolova 2017). Clearly, such soft extractivism did not perform the same level of symbolic and physical violence and economic warfare as the extractivist capitalism suffered by the post-colonial world. Dealing with countries from the latter, Eastern European socialist countries did not engage in extractive capitalism i.e. "an economic system that engages in thefts, borrowings, and forced removals, violently reorganizing social life as well as the land by thieving resources from indigenous... territories" (Gómez-Barris 2017: xvii). The latter paradigm of colonial and neo-colonial rule was the negative background against which socialist efforts of solidarity were framed. Keeping this distinction in mind, it is still however important to reflect on the significance of the asymmetry of the trade and knowledge exchange between Eastern European countries and the Global South during the Cold War. How do we explain the one-sidedness of the educational exchange in which 'expertise' and technology continuously only came from those positioned in Europe and raw materials only came from those positioned outside of it? What are the lessons that such asymmetries teach us about how to design new internationalist programmes in the present and future based on horizontal relations of mutual learning and solidarity? How, then - to return to and rethink the initial question of my study - can we 
speak of alternative modes of knowledge production and exchange, if its exchange depends on and indeed reproduces a neo-colonial economic model?

Alena Alamgir (2013) speaks of three types of internationalism that drove relations between state-socialist countries in Eastern Europe as Czechoslovakia and 'third world' developing economies in the Global South as Vietnam at different stages of the development of the Cold War. These three types were constructed through bilateral trade contracts and debt agreements. Alamgir calls them paternalistic internationalism, mutually advantageous internationalism, and beleaguered internationalism (Alamgir 2013). Based on this definition and temporalisation, Raia Apostolova's analysis of the Bulgarian-Vietnamese relations suggests that Bulgaria initially practiced a mixed model of paternalistic and mutually advantageous internationalism (Apostolova 2017: 106). The latter saw workers as practitioners, symbol of internationalist duty and solidarity. Gradually, however, as Apostolova demonstrates, by the 1980s this model transformed into one that instrumentalised and racialized workers and reduced them to tools of debt repayment (Apostolova 2017: 108). Apostolova also shows that while initially the research-informed state policy solicited an equal exchange between workers from both countries, so that Vietnam was not an inactive recipient of aid, the exchange became increasingly asymmetric as years went by (Apostolova 2014: 204).

Zoltan Ginelli's work (2018) has also showed the workings of what he has called 'semiperipheral post-colonialism'. In his recent article on expert exchange between Hungary and Ghana, Ginelli argues that while allowing for socialist interconnectivity and infrastructural development of African countries, such exchange was not necessarily equal in benefits. While semi-peripheral experts developed transferable know-how and careers that had transversal currency across the so-called 'first', 'second', and 'third' worlds, they did this by reinforcing the presumed dominance of Eurocentric knowledge. He also explains that the 
ambiguities of a semi-peripheral position also meant that instead of challenging the 'civilizational' mission of Europe in the post-colonial world, East European countries embraced this Eurocentric vision of the world and compromised their own anti-imperialist decolonial commitment (Ginelli 2018).

This development is mirrored in the discussion of the asymmetric internationalisation of higher education in the present day. It also connects with the most recent scholarship on the student exchange between the socialist and the post-colonial world during the Cold War, developed especially in works focused on East Germany (for example Pugach 2018; Burton 2019). For instance, Sara Pugach (2018) has reminded us that not only governments in Western liberal democracies but also those in state socialist countries believed in scientific modernity's developmentalist premise and promise that technological solutions and expert knowledge would solve the problem of 'underdevelopment' in the Global South. Students from post-colonial countries, often internalising the same values that put them at disadvantage, came from nations where few were exposed to the luxury of higher education and mostly in Western institutions. As such, Pugach's argument goes, they saw Eastern European countries as sufficiently advanced to offer the education at Western standards (Pugach 2018: 1). Such education, however, also entailed the modern secular outlook that went with it (Pugach 2018: 11), often at the expense of upholding local systems of knowledge, science and tradition that donot fit into the Western canon (Santos 2013). At the same time, socialist countries in the North also controlled the number of students they would receive from their Southern counterparts and which subjects they would train them in (Pugach 2018: 15), which gave them more power over planning of knowledge and technology transfer than the countries sending their students to be trained abroad. And while students and workers from developing countries were often exposed to 'hygienising' and 'civilising' in Northern socialist societies (Apostolova 2017; Ginelli 2018; Pugach 2018), 
they often had to face racist violence that state socialist countries turned a blind eye to (Hessler 2006) or sometimes even institutionalised (Apostolova 2017).

Added to this extractivist effort, the 'civilising' and often racializing practices show significant compromise with an anti-colonial agenda. Together, they merit the discussion, finally, of a concept that nowadays has significant currency in the discussion of past and present internationalist efforts especially when it comes to educational and knowledge exchange. The subject of decolonialising of knowledge has recently become prominent both within and outside the field of HE studies. One of the leading voices of decolonial theory, Portuguese philosopher Boaventura de Sousa Santos, posits that: '[T]echno-scientific knowledge... owes its hegemony to the credible way in which it discredits all rival knowledges, by suggesting that they are not comparable, in terms of efficiency and coherence, to the scientificity of the market laws' (Santos 2013: 13). This type of knowledge, traditionally connected to and produced in countries in the Global North, perpetuates their dominance by presenting itself as universal while discarding the value of alternative knowledges produced outside these countries. At the same time, this means that some knowledges are rendered visible and valuable while others are invisibilised, marginalised, and seen as lacking value (Santos 2013; Guzman-Valenzuela and Gomes 2019). In the past and present alike, countries in the world system semi-periphery often embrace the symbolic and empirical dominance of Eurocentric knowledge institutions and reproduce it in their own self-peripheralisation and asymmetric knowledge exchange with those further 'down' the symbolic ladder (Ivancheva and Syndicus 2019). When exploring the internationalisation of higher education, it is of crucial importance to rethink the actual practices of and perils to counter-hegemonic HE partnerships and exchanges across the world, past and present. 


\section{Coda}

Standing in an ambiguous relationship to the former socialist world (Ginelli 2018), decolonial thinking has more recently been appealed to as "helpful in appreciating [Eastern European]'s imperial and (quasi-)colonial legacy, in analysing contemporary forms of domination, hierarchy and resistance, and for identifying their corresponding practices of complicity and collaboration, but also of struggle, protest and reversals of the current neoliberal trajectory" (Kusic et al. 2019: 8). Bringing the discussion of decolonial thinking to the HE exchange and knowledge production during the Cold War, it is also important to consider concepts as cognitive justice (Visvanathan 2006) i.e. the recognition of the plurality of knowledges in dialogue, rather than imposition of one as universally valid. In this, if the East-South knowledge and expert exchange remained one-sided, it is worth examining its asymmetries in further depth. In this process, it is especially important to ask if the HE exchange and knowledge production go beyond the arithmetic of economic exchange or it followed its main premise: instrumentalising human and natural resources to its benefit while casting alternative knowledge systems into its mould.

Against this background, the present study is a first step in a bigger research project: one that traces HE expert cadre and student exchange between countries in the socialist bloc and countries in the postcolonial world. Such study should ask if this exchange was based on the premise of superiority of Eurocentric knowledge and expertise or did it develop an alternative decolonial epistemology? Did the extractive and asymmetric nature of the exchange render alternative epistemologies develop from the grassroots invisible in the archived documents under layers of official propaganda? What are the heuristic tools that would enable such an exploration, allowing for a more nuanced reading while avoiding the usual traps of total celebration or total rejection of the achievements of state socialist internationalism? 
Further research on these topics should explore the East-South and South-South socialist HE exchange on two levels. First, we need to study the exact agreements that individual countries signed and the framing of qualification levels and position of experts and students in the process. Such studies could also explore the framing of travel regimes of high- and low-skill labour, capital (debt) and commodities (both primary goods and technologies). Second, it would be interesting to trace if there was different periodization in the exchange between countries when it came to HE experts and students and if so, what were the turning points that changed the frame of this exchange.

\section{Bibliography}

Alamgir, A. K. (2013). Race is elsewhere: state-socialist ideology and the racialisation of Vietnamese workers in Czechoslovakia. Race \& Class, 54(4), 67-85. https://doi.org/10.1177/0306396813476171 Apostolova, R. (2017). Duty and Debt under the Ethos of Internationalism: The Case of the Vietnamese Workers in Bulgaria. Journal of Vietnamese Studies, 12(1), 101-125. https://doi.org/10.1525/jvs.2017.12.1.101

Burton, E. (2019). Navigating global socialism: Tanzanian students in and beyond East Germany. Cold War History, 19(1), 63-83. https://doi.org/10.1080/14682745.2018.1485146 Coronil, F. (1997). The magical state: nature, money, and modernity in Venezuela. Chicago: University of Chicago Press.

David-Fox, M. (2016). Revolution of the mind. Retrieved from http://www.jstor.org/stable/10.7591/j.ctt1g69x88

Djagalov, R., \& Christine Evans. (2009). Moskau, 1960: Wie man sich eine sowjetische Freundschaft mit der Dritten Welt vorstellte. In Andreas Hilger (Ed.), Die Sowjetunion und 
die Dritte Welt. UdSSR, Staatssozialismus und Antikolonialismus im Kalten Krieg 19451991. Munich: Oldenbourg.

Filatova, I. (1999). Indoctrination or Scholarship? Education of Africans at the Communist University of the Toilers of the East in the Soviet Union, 1923-1937. Paedagogica Historica, 35(1), 41-66. https://doi.org/10.1080/0030923990350104

Frank, D. J., \& Meyer, J. W. (2007). University expansion and the knowledge society. Theory and Society, 36(4), 287-311. https://doi.org/10.1007/s11186-007-9035-z

Galeano, E. (2009). Open veins of Latin America five centuries of the pillage of a continent. London: Serpent's Tail.

Ginelli, Z. (2018). Hungarian Experts in Nkrumah's Ghana. Retrieved from http://mezosfera.org/hungarian-experts-in-nkrumahs-ghana/

Gómez-Barris, M. (2017). The extractive zone: social ecologies and decolonial perspectives. Durham ; London: Duke University Press.

González, J. C., Hickling-Hudson, A., \& Lehr, S. (2012). Challenging Educational Underdevelopment: The Cuban Solidarity Approach as a Mode of South-South Cooperation. In A. Hickling-Hudson, J. C. González, \& R. Preston (Eds.), Capacity to share: a study of Cuba's international cooperation in education development (pp. 35-52).

https://doi.org/10.1057/9781137014634 3

Guzmán-Valenzuela, C., \& Gómez, C. (2019). Advancing a knowledge ecology: changing patterns of higher education studies in Latin America. Higher Education, 77(1), 115-133. https://doi.org/10.1007/s10734-018-0264-z

Hatzky, C. (2012). Cuba's Educational Mission in Africa: The Example of Angola. In A. Hickling-Hudson, J. C. González, \& R. Preston (Eds.), Capacity to share: a study of Cuba's international cooperation in education development (pp. 141-159).

https://doi.org/10.1057/9781137014634_9 
Hessler, J. (2006). Death of an African Student in Moscow: Race, politics, and the Cold War. Cahiers Du Monde Russe, 47(47/1-2), 33-63. https://doi.org/10.4000/monderusse.9591 Hickling-Hudson, A., González, J. C., \& Preston, R. (Eds.). (2012). Capacity to share: a study of Cuba's international cooperation in education development. New York: Palgrave Macmillan.

Holečková, M. E. (2018). Univerzita 17. listopadu a její místo v československém vzdělávacím systému a společnosti (Charles University). Retrieved from https://is.cuni.cz/webapps/zzp/detai1/103171/

Ivancheva, M. P. (2017). Between Permanent Revolution and Permanent Liminality: Continuity and Rupture in the Bolivarian Government's Higher Education Reform. Latin American Perspectives, 44(1), 251-266. https://doi.org/10.1177/0094582X16666021 Ivancheva M.P \& Syndicus, I. (2019). Introduction: Higher education reform in the ‘periphery'. Learning and Teaching, 12(1): 1-16 https://doi.org/10.3167/latiss.2019.120101 Katsakioris, C. (2017). Creating a Socialist Intelligentsia. Soviet Educational Aid and its Impact on Africa (1960-1991). Cahiers d'études Africaines, 226(2), 259-288. Retrieved from Cairn.info.

Keller, E. J. (Ed.). (1987). Afro-Marxist regimes: ideology and public policy. Boulder, Colo.: Rienner.

Kušić, K., Lottholz, P., \& Manolova, P. (2019). From dialogue to practice: Pathways towards decoloniality in Southeast Europe. Dversia, 3/19(Special Issue: Decolonial Theory and Practice in Southeastern Europe).

Marginson, S. (2008). Global field and global imagining: Bourdieu and worldwide higher education. British Journal of Sociology of Education, 29(3), 303-315. https://doi.org/10.1080/01425690801966386 
Matusevich, M. (2008). Journeys of Hope: African Diaspora and the Soviet Society. African Diaspora, 1(1), 53-85. https://doi.org/10.1163/187254608X346033

Nash, M. (Ed.). (2016). Red Africa: affective communities and the Cold War. London, UK: Black Dog Publishing.

Pérez, L. (2018). Sugar, Cigars, and Revolution: The Making of Cuban New York. New York: New York University Press.

Pugach, S. (2018). Eleven Nigerian Students in Cold War East Germany: Visions of Science, Modernity, and Decolonization. Journal of Contemporary History, 002200941880343. https://doi.org/10.1177/0022009418803436

Romano, A., \& Romero, F. (2014). European Socialist regimes facing globalisation and European co-operation: dilemmas and responses - introduction. European Review of History: Revue Européenne d'histoire, 21(2), 157-164.

https://doi.org/10.1080/13507486.2014.888711

Santos, B. de S. (2013). Epistemologies of the South: justice against epistemicide. Boulder: Paradigm Publishers.

Visvanathan, S. (2006). Alternative Science. Theory, Culture \& Society, 23(2-3), 164-169. https://doi.org/10.1177/026327640602300226

\section{Archival materials consulted during my stay at OSA}

\section{HU-OSA-300-20-1 RFE Subject File Bulgarian Unit Subject Files, archival boxes:}

\#18, Communist Party: Party Education

\#42, Culture: People's Education; Bulgarian Academy of Sciences

\#56 Education: Universities and Colleges; Vocational Schools; Education in Other Countries \#79 Foreign Relations: Relations with other countries: Africa; \#80 Foreign Relations: Relations with other countries: Angola; Burkina Faso; Cape Verde; 
\#90 Foreign Relations: Relations with other countries: Cuba

\#91 Foreign Relations: Relations with other countries: Ethiopia

\#97 Foreign Relations: Relations with other countries: Ghana; Guinea; Guinea Bisau

\#109 Foreign Relations: Relations with other countries: Mozambique

\#116 Foreign Relations: Relations with other countries: Tanzania

\#129 Foreign Relations: Relations with other countries: Zaire; Zimbabwe

\#160 Labour: Bulgarian Workers and Specialists in Foreign Countries

\#191 Trade Foreign: Africa; Angola

\#192 Trade Foreign: Cuba; Ethiopia

\#193 Trade Foreign: Ghana

\#196 Trade Foreign: Mozambique

\#197 Trade Foreign: Tanzania

\#202 Trade Foreign: Zaire; Zimbabwe

\#206 Youth Students; Organization

HU OSA-300-20-2 - RFE Bulgarian Unit Subject Card Files:, archival boxes

\#48-49 Higher Education (general); public universities; foreign students;

\#58 Foreign Policy: Angola; Burkina Faso;

\#59 Foreign Policy: Ghana; Guinea, Guinea Bisau

\#60 Foreign Policy: Ethiopia; Zaire; Zimbabwe

\#61 Foreign Policy: Cuba

\#62 Foreign Policy: Mozambique

\#65 Foreign Policy: Tanzania

HU OSA 301-0-3 - RFE Records of Index on Censorship: Country Files, archival boxes: \#8-9 Africa: Angola: General; Education

\#118-119 America: West Indies: Cuba: Background Information; General; Education 
HU OSA 300-7-9 Subject Files Re: World Communist Movement, archival boxes:

\#41-43 Conference: East-West Academic; International

\#55 Youth Movement: Communist

HU OSA 300-55-10 Subject Files

\footnotetext{
${ }^{\mathrm{i}}$ I also consulted individual files that had the combination of country name-plus-education, and there were some interesting individual entries, however the majority were from the subject files. I also went through the subject files that spoke of education, higher education, universities. Given the specific of this collection, gathered as interviews of individual migrants escaping the socialist bloctoward the West, it provided an interesting but rather subjective perspective on the developments in the socialist countries. The information was collected from people - often students in HEIs or workers at popular/workers colleges - with first-hand experience with educational institutions, but little institutional responsibility, so without a source of triangulation, the documents could hardly serve as source of institutional policy direction.
} 